\title{
Purification of a new fungal mannose-specific lectin from Penicillium chrysogenum and its aphicidal properties
}

\section{Frédéric FRANCIS ${ }^{a, *}$, Karimi JABER ${ }^{a}$, Frédéric COLINET ${ }^{b}$, Daniel PORTETELLE $^{b}$, Eric HAUBRUGE ${ }^{a}$}

${ }^{a}$ Functional \& Evolutionary Entomology, Gembloux Ago-Bio Tech, University of Liege, Passage des Déportés 2, B-5030 Gembloux, Belgium ${ }^{\mathrm{b}}$ Microbiology \& Animal Biology, Gembloux Ago-Bio Tech, University of Liege, Passage des Déportés 2, B-5030 Gembloux, Belgium

\section{A R T I C L E I N F O}

Article history:

Received 21 April 2010

Received in revised form

16 May 2011

Accepted 13 June 2011

Corresponding Editor: Judith K. Pell

Keywords:

Bioinsecticide

Lectin

Mushroom

Myzus persicae

Penicillum chrysogenum

Purification

\begin{abstract}
A B S T R A C T
Several Ascomycetes fungi are commonly used in bio-industries and provide available industrial residues for lectin extraction to be valuable. A lectin from Penicillium chrysogenum, named PeCL, was purified from a fungal culture using gel-filtration chromatography column. PeCL was found to be a mannose-specific lectin by haemagglutination activity towards rabbit erythrocyte cells and was visualised on SDS-PAGE gel. Purified PeCL fraction was delivered via artificial diet to Myzus persicae aphid and was demonstrated to be aphicidal at $0.1 \%$ with higher toxic efficiency than a known mannose-binding lectin Concanavalin A (ConA). A fast and efficient way to purify PeCL and a potential use in pest control is described.
\end{abstract}

(c) 2011 British Mycological Society. Published by Elsevier Ltd. All rights reserved.

\section{Introduction}

Lectins are carbohydrate-binding proteins that are widely distributed in nature and play different roles and functions in biological processes such as recognition molecules within the immune system in animals (Kilpatrick 2002) and as storage proteins or in defence mechanisms against pest and pathogens in plants (Peumans \& Van Damme 1995; Van Damme et al. 1998; Rudiger \& Gabius 2001). Lectins have also been purified from fungi and were found to be involved in host recognition, cell surface adhesion, antiproliferative action and endocytosis (Guillot \& Konska 1997; Francis et al. 2003; Ng 2004; Wang et al. 2006). In particular, the use of endophytic fungi producing lectin was found to be a promising way to deliver insecticidal proteins to control sap-sucking pests for crop protection (Qi et al. 2011). By example, Sclerotinia sclerotiorum agglutinin induced a high mortality on Acyrthosiphon pisum fed with fungal lectin in artificial diet (Hamshou et al. 2010). Only a few lectins have been extracted from Ascomycetes (Jung et al. 2007) even if some of these fungi are very common in bio-industries. Among them, Penicillum chrysogenum was selected here due to its very common availability and the potential use of industrial residues as a source of potential bioinsecticide proteins. Indeed, the ability of lectins to interact with carbohydrates and combine with glycol-components of cell surface has been investigated to find toxic proteins to control insect pests as alternative methods to conventional chemical control (Macedo et al. 2007). A range of Hemiptera including aphids cause serious damage to many

\footnotetext{
* Corresponding author. Tel.: +32 81 622283; fax: +32 81622312.

E-mail address: Frederic.Francis@ulg.ac.be
}

1878-6146/\$ - see front matter @ 2011 British Mycological Society. Published by Elsevier Ltd. All rights reserved. doi:10.1016/j.funbio.2011.06.010 
crop plants by directly sucking plant sap and by indirectly acting as virus vectors (Barton et al. 1987; Peferoen et al. 1990).

Lectins have obvious potential as insect control agents although knowledge as to the mechanisms of lectin action is limited. Insecticidal lectins have been shown to be bound to midgut epithelial cells in a variety of pest species (Habibi et al. 1998, 2000). In some cases, damage to structure of gut epithelium, such as that observed by Powell et al. (1998) in the Hemiptera Nilaparvata lugens has led to suggestions that binding may be a causative factor in the toxicity of a wide range of lectins to insects. The sensitivity of different insect species to the effects of lectin ingestion is variable, and binding of a particular lectin to the gut of a given species does not necessarily facilitate insecticidal activity (Harper et al. 1995). The blockage of the peritrophic matrix pores by lectins was at least in part responsible for observed insect starvation effects. Bioassays with Con A corresponded to the highest observed toxicity among the tested lectins towards several insect species (Fitches et al. 2001) and lead to the selection of Concanavalin A (ConA) has referenced insecticidal lectin in further assays. Some previous studies have been conducted which have shown mannose-binding plant lectins with antimetabolic properties towards Hemiptera insect pests including aphids, planthoppers, and leafhoppers (Sauvion et al. 1996; Powell 2001). However, relatively few studies have focused on the potential use of fungal-derived lectins to achieve this aim. Here, a lectin from $P$. chrysogenum was purified in a simple protocol based on gel-filtration chromatographic technique. The characterisation of the lectin was performed by haemagglutination assays in the presence of various carbohydrates and by electrophoresis. Finally, the toxicological effect of the purified lectin was determined on a single aphid species Myzus persicae Sultzer. The potential use of this fungal lectin as mycoinsecticide is discussed in relation to the development of biological control molecules to target major crop pests.

\section{Materials and methods}

\section{Fungal growth and purification procedure}

Penicillum chrysogenum was cultured in 863 medium (peptone $10 \mathrm{~g}$, glucose $20 \mathrm{~g}$, and yeast extract $10 \mathrm{~g}$ ) in $300 \mathrm{ml}$ Erlenmeyer flasks with a $200 \mathrm{ml}$ working volume on a rotary shaker (150 rpm) at $30^{\circ} \mathrm{C}$ for $96 \mathrm{~h}$. The culture broth was filtered through a vacuum pump and mycelium was collected. Forty grams of harvested mycelia were ground into powder in liquid nitrogen. Proteins from the mycelium powder were extracted in phosphate buffered saline (PBS: $8 \mathrm{mM} \mathrm{Na}_{2} \mathrm{HPO}_{4}, 1.5 \mathrm{mM} \mathrm{KH} \mathrm{PO}_{4}$, $137 \mathrm{mM} \mathrm{NaCl}$, and $2.7 \mathrm{mM} \mathrm{KCl}, \mathrm{pH}, 7.4$ ) and the homogenate was filtered through cheesecloth before being centrifuged at $15000 \mathrm{~g}$ for $20 \mathrm{~min}$ at $4{ }^{\circ} \mathrm{C}$. The supernatant was collected and concentrated 10 times by ultrafiltration $(3000 \mathrm{Da})$ at $4000 \times \mathrm{g}$ and $4{ }^{\circ} \mathrm{C}$ and applied to a prepacked column $16 / 70$ connected with a FPLC Äkta (GE Healthcare, Diegem, Belgium). Proteins were eluted with $150 \mathrm{ml}$ of PBS pH 7.4, the flow was fixed at

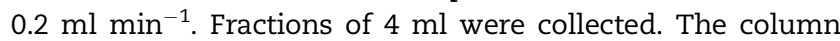
has been calibrated with a GE Healthcare molecular weight marker kit (Ovalbumin $43000 \mathrm{Da}$, Carbonic anhydrase $29000 \mathrm{Da}$, Ribonuclease A $13700 \mathrm{Da}$, and Aprotinin $6500 \mathrm{Da}$ ).
Fraction size: $4 \mathrm{ml}$; injection at 'Elution $=0 \mathrm{ml}$ '; flow rate: $0.2 \mathrm{ml} \mathrm{min}^{-1}$; absorbance at $280 \mathrm{~nm}$.

\section{Haemagglutination activity and inhibition assays}

Rabbit erythrocytes were used for the determination of haemagglutination activity. The erythrocyte cells were washed (three times) in PBS (4\% v v $\left.{ }^{-1}, \mathrm{pH} 7.4\right)$, centrifuged $(2000 \times \mathrm{g}$, for $15 \mathrm{~min}$ at $4{ }^{\circ} \mathrm{C}$ ), and resuspended in PBS. For haemagglutination assays, $50 \mu \mathrm{l}$ of two-fold serial dilutions of the protein extracts were mixed with an equal volume of a $4 \%$ erythrocyte suspension in wells of U-shaped microtiter plates. The plates were allowed to settle at room temperature for $2 \mathrm{~h}$ when the negative control had fully sedimented.

Inhibition assays using carbohydrates were performed by serial two-fold dilutions of specific sugars in PBS. The tested carbohydrates were D-fructose, D-galactose, D-glucose, D-mannose, Sucrose, N-acetyl-D-glucosamine, N-acetyl-D-galactosamine, and L-fructose. Each dilution was mixed with an equal volume $(25 \mu \mathrm{l})$ of protein sample and allowed to stand for $30 \mathrm{~min}$ at $4{ }^{\circ} \mathrm{C}$ before mixing with $50 \mu \mathrm{l}$ of $4 \%$ rabbit erythrocyte suspension. The haemagglutination activity was conducted as described above. The minimum concentration of each tested sugar in the final reaction mixture allowing complete inhibition of haemagglutination units was recorded.

\section{Protein concentration determination}

Protein concentrations were determined according to the Bradford method with bovine serum albumin as the standard (Bradford 1976).

\section{Protein denaturation}

For analytical SDS/PAGE, samples were diluted 1:4 with a solubilizer (1 \% SDS; $0.02 \%$ bromophenol; $1 \%$ betamercaptoethanol in running buffer) and boiled for $3 \mathrm{~min}$ before electrophoresis. Separation gels were $12 \%$ acrylamide/0.01\% SDS in $0.5 \mathrm{M}$ Tris- $\mathrm{HCl} \mathrm{pH}$ 8.8. Stacking gels were $3.5 \%$ of acrylamide in $1.5 \mathrm{M}$ Tris- $\mathrm{HCl}, \mathrm{pH}$ 6.8. A conventional buffer system (Laemmli 1970) was used with a $10 \times$ running buffer are $2 \mathrm{M}$-glycine/0.1\% SDS/0.4 M Tris, pH 8.3. Electrophoresis was carried out at $100 \mathrm{~V}$ for $1 \mathrm{~h} 30 \mathrm{~min}$ in a Slab gel system (BioRad). Gels were stained with $0.1 \%$ Coomassie brilliant blue.

\section{Protein identification}

An aliquot from fraction 9 related to the purified PeCL from the gel-filtration was sampled and the protein was precipitated using a conventional Trichloroacetic acid (TCA)/acetone procedure. Acrylamide gel bands corresponding to the two bands from the SDS-PAGE were also sampled to be trypsin digested. Protein pellet was resuspended in $20 \mu \mathrm{l}$ of $50 \mathrm{mM} \mathrm{NH}_{4} \mathrm{HCO}_{3}$, $\mathrm{pH}$ 8.0. Cysteines were reduced with $1 \mu \mathrm{l}$ of a $200 \mathrm{mM}$ dithiothreitol (DTT) solution in $100 \mathrm{mM} \mathrm{NH}_{4} \mathrm{HCO}_{3}$ for $10 \mathrm{~min}$ at $50{ }^{\circ} \mathrm{C}$ followed by alkylation for $45 \mathrm{~min}$ with $0.8 \mu \mathrm{l}$ of a $50 \mathrm{mM}$ iodoacetamide solution in $100 \mathrm{mM} \mathrm{NH}_{4} \mathrm{HCO}_{3}$ at room temperature in the dark. Alkylation was halted by neutralizing the remaining iodoacetamide through the addition 
of $4 \mu \mathrm{l}$ of a $200 \mathrm{mM}$ DTT in $100 \mathrm{mM} \mathrm{NH}_{4} \mathrm{HCO}_{3}$ at room temperature for $45 \mathrm{~min}$. Digestion was then performed overnight with $0.1 \mu \mathrm{g}$ of trypsin in water. The resulting peptides were dried in a vacuum centrifuge and resuspended in $30 \mu \mathrm{l}$ of $0.1 \%$ formic acid in water. Peptide separation by reversed-phase liquid chromatography was performed on an Ultimate LC system (LC Packings) complete with Famos autosampler and Switchos II microcolumn switching device for sample clean-up and preconcentration. A $30 \mu \mathrm{l}$ sample was loaded at a flow rate of $200 \mathrm{~nL} \mathrm{~min}^{-1}$ on a micro-precolumn cartridge $(300 \mu \mathrm{m}$ i.d. $\times 5 \mathrm{~mm}$, packed with $5 \mu \mathrm{m}$ C18 $100 \AA$ PepMap). After $5 \mathrm{~min}$, the precolumn was connected with the separating nano-column $(75 \mu \mathrm{m}$ i.d. $\times 15 \mathrm{~cm}$, packed with C18 PepMap100, $3 \mu \mathrm{m}, 100 \AA$ ) and the gradient started. Elution gradient varied from $0 \%$ to $30 \%$ buffer B over $30 \mathrm{~min}$, buffer $\mathrm{A}$ is $0.1 \%$ formic acid in acetonitrile/water $2: 98\left(\mathrm{v} \mathrm{v}^{-1}\right)$ and buffer $\mathrm{B}$ is $0.1 \%$ formic acid in acetonitrile/water 20:80 $\left(\mathrm{v} \mathrm{v}^{-1}\right)$. The outlet of the LC system was directly connected to the nano electrospray source of an Esquire HCT ion trap mass spectrometer (Bruker Daltonics, Germany). Mass data acquisition was performed in the mass range of $50-1700 \mathrm{~m} \mathrm{z}^{-1}$ using the StandardEnhanced mode $\left(8100 \mathrm{~m} \mathrm{z}^{-1} \mathrm{~s}^{-1}\right)$. For each mass scan, a datadependant scheme picked the four most intense double- or triple-charged ions to be selectively isolated and fragmented in the trap and the resulting fragments were mass analysed using the Ultra Scan mode $\left(50-3000 \mathrm{~m} \mathrm{z}^{-1}\right.$ at $\left.26000 \mathrm{~m} \mathrm{z}^{-1} \mathrm{~s}^{-1}\right)$. Raw data were analysed and formatted (Data Analysis software, Bruker) for subsequent protein identification against the NCBI nonredundant protein database through the MS/MS ions search algorithm on the Mascot search engine (www.matrixscience.com). The mass tolerance of precursor and sequence ions were set at 0.5 and $0.3 \mathrm{Da}$, respectively, and carbamidomethylation of cysteines and methionine oxidation were set as fixed and variable modifications, respectively.

\section{Aphid rearing and in vitro toxicological testing}

Myzus persicae aphids used in this study were reared for many years on broad beans (Vicia faba L.) at $20 \pm 2{ }^{\circ} \mathrm{C}, 16 \mathrm{~h}$ photoperiod before being used for artificial diet bioassays. The composition of the diet and the chamber methodology used in all experiments was the A5 diet (Febvay et al. 1988) with a sucrose content adjusted to $15 \%$. Diet was filtered through a $20 \mu \mathrm{m}$ membrane and used immediately or aliquots are stored at $-20^{\circ} \mathrm{C}$ until used. Diet sachets (two layers of parafilm enclosing $150 \mu \mathrm{g} \mathrm{ml}^{-1}$ of diet) were changed every $2 \mathrm{~d}$. Twenty neonate aphids ( $24 \mathrm{~h}$ old) in five replicates (total of 100 insects) were deposited on artificial diets supplemented with the purified PeCL lectin at $0.1 \%\left(\mathrm{w} \mathrm{v}^{-1}\right)$. Aphid mortality rates were determined for up to $5 \mathrm{~d}$ using a range from 0 to $2 \mathrm{mg} \mathrm{ml}^{-1}$ of PeCL or ConA (Sigma, Bornem, Belgium) and compared to lectin-free diet. All diet transfers and manipulations were performed under sterile conditions.

\section{Statistical analysis}

Results from the toxicological assays were analyzed by Minitab Software (version 13.1) using analysis of variance and Tukey mean test.

\section{Results}

\section{Lectin purification}

A chromatogram relating to Penicillum chrysogenum lectin (PeCL) shows a peak of haemagglutination activity presented in Fig 1. A summary of PeCL yield and efficiency is shown in Table 1.

Fractions 8-11 showed high haemagglutination activity. The specific haemagglutining activity of the crude extract was

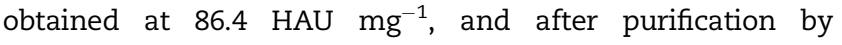
gel-filtration, the specific activity was increased up to 1062.0 HAU mg ${ }^{-1}$ for fraction 9. A more than 12 -fold purification ratio was obtained.

\section{Haemagglutination inhibition assays}

To characterise the carbohydrate-binding specificity of PeCL, different sugars were used to assess the haemagglutination activity of the purified fungal lectin (Table 2). An inhibition of the haemagglutination activity was observed from $39.1 \mu \mathrm{g}$ of added mannose. None of the other tested carbohydrates showed any inhibition of the haemagglutination at up to $312.5 \mu \mathrm{g}$ sugar.

The active purified fractions (fraction 9 and $60 \%$ precipitation) were subjected to SDS-PAGE for molecular mass and quality purification. Two bands, of 31 and $40 \mathrm{kDa}$ respectively, were observed and related to the FPLC-Sephadex G-75 column purified PeCL (Fig 2).

\section{Protein identification}

According to the LC-MS-MS analysis, the identified peptides, namely ISAV, KTKTSS, LVEAE, LGGVG, FTPAELAHH were not found to show significant homology when compared to the available sequences from the NCBI database. Only one positive match was obtained with a mannose-binding lectin from Zea mays (Accession number AAZ30382) based on the VAVQDDG amino acid sequence.

\section{Toxicity assays using purified PeCL}

Toxicological assays were carried out to assess the potential effect of the PeCL purification fractions on Myzus persicae mortality on alternate days up to $5 \mathrm{~d}$ (Fig 3). Significant differences in mortality were observed between PECL and control diet fed aphids after $5 d(F=5.96, P<0.05)$ mainly, with PeCL gel-filtration fraction 9 after $1 d(t=3.67$ and $P<0.05), 3 d(t=5.98$ and $P<0.001)$ and after $5 d(F=15.75, P<0.001)$. No significant difference in aphid mortality related to the two controls, namely the lectin-free diet and the diet including inert fraction 35 (containing PBS). Myzus persicae mortality was higher when fed on artificial diet containing $0.1 \%$ PeCL than aphid fed with $0.1 \%$ ConA common lectin reference, after 3 and $5 \mathrm{~d}$ $(t=-3.25,-3.96, P<0.05)$.

A range of PeCL concentrations (from 0.1 to $2 \mathrm{mg} \mathrm{ml}^{-1}, \mathrm{w} \mathrm{v}^{-1}$ corresponding to $0.01-0.2 \%$ lectin concentrations) from the most active fraction (fraction 9) were incorporated into artificial diet and fed to M. persicae. The LC50 value was determined to be $0.4 \mathrm{mg} \mathrm{ml}^{-1}$ of purified PECL lectin. A comparison with the reference ConA lectin was performed and demonstrated the 


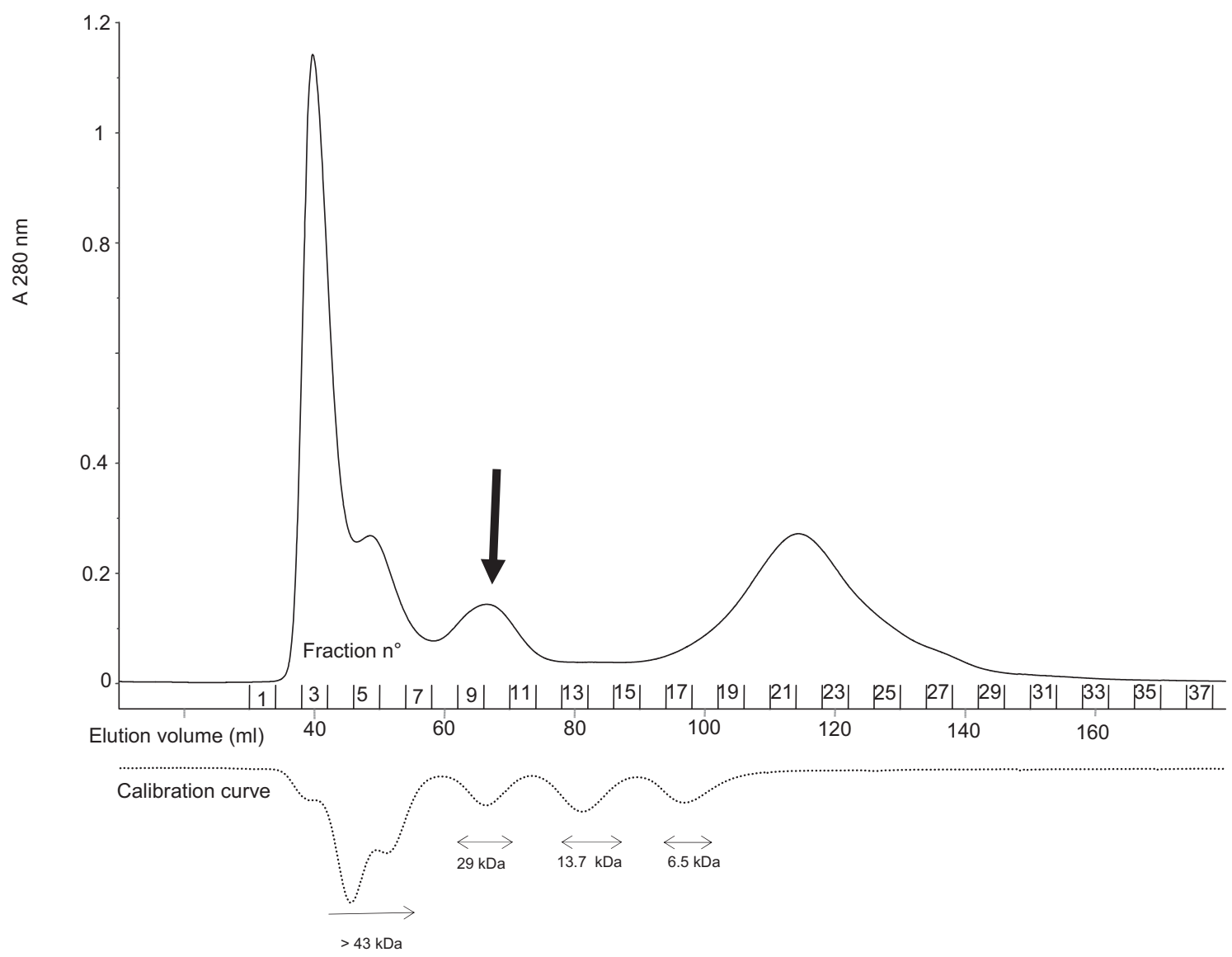

Fig 1 - Chromatogram related to the lectin purification from Penicillium chrysogenum by gel-filtration. The arrow indicates the active lectin fraction.

relatively high toxic effect of PECL on $\mathrm{M}$. persicae compared to ConA (Fig 4).

Significant differences in M. persicae mortality were observed when fed with PeCL and ConA in artificial diets after $1 \mathrm{~d}$ at $0.1 \%(F=6.02, P<0.05)$, after 3 and $5 \mathrm{~d}$ from $0.5 \%$ $(t=6.54,5.50$ and $P<0.05)$. High significant differences were observed in aphid mortality rates at highest dose, $0.2 \%$ corresponding to $2 \mathrm{mg} \mathrm{ml}^{-1}$, when PECL and ConA treatments were compared after $5 \mathrm{~d}(F=16.07, P<0.001)$. Therefore, the effect on $M$. persicae of both lectins differed, PeCL showed higher toxic efficiency than the ConA reference lectin.

\section{Discussion}

Fungi contain various potential insecticidal proteins, including ribosome inactivating proteins, proteases, nucleases and lectins (Ng 2004). Until now, a range of mushroom lectins including, Xerocomus chrysenteron lectin (XCL), Agaricus bisporus lectin (ABL), and Arthrobotrys oligospora lectin (AOL) have been isolated and all of which induce reversible antiproliferative effects on different cell types (Wang et al. 1998; Oda et al. 2003; Ng 2004). Among fungi systematic, Ascomycetes are found in a broad

Table 1 - Purified fractions of lectin from Penicilium chrysogenum by gel-filtration.

\begin{tabular}{|c|c|c|c|c|c|c|}
\hline Step & $\begin{array}{l}\text { Volume } \\
(\mathrm{ml})\end{array}$ & $\begin{array}{l}\text { Total protein }{ }^{\mathrm{a}} \\
\text { (mg) }\end{array}$ & Total HAU ${ }^{\mathrm{b}}$ & $\begin{array}{c}\text { Specific activity } \\
\text { HAU }^{\mathrm{b}} \mathrm{mg}^{-1}\end{array}$ & $\begin{array}{l}\text { Purification } \\
\text { fold }\end{array}$ & $\begin{array}{l}\text { Recovery } \\
\text { activity\% }\end{array}$ \\
\hline Crude extract & 40 & 23.2 & 3200 & 86.4 & 1.0 & 100 \\
\hline Fraction 8 & 4 & 0.9784 & 320 & 327.2 & 3.8 & 10 \\
\hline Fraction 9 & 4 & 0.7792 & 640 & 821.0 & 9.5 & 20 \\
\hline Fraction 10 & 4 & 0.6024 & 640 & 1062.0 & 12.3 & 20 \\
\hline Fraction 11 & 4 & 0.5408 & 80 & 147.9 & 1.7 & 3 \\
\hline
\end{tabular}

a Protein concentration as determined according to the method of Bradford (1976).

b Haemagglutination activity unit. 
Table 2 - Effect of various carbohydrates on

haemagglutination activity from Penicillum chrysogenum lectin.

\begin{tabular}{|c|c|c|c|c|c|c|}
\hline \multirow[t]{2}{*}{ Sugar } & \multicolumn{6}{|c|}{ Sugar quantity $(\mu \mathrm{g})$ for one HAU ${ }^{\mathrm{a}}$} \\
\hline & 312.5 & 156.3 & 78.1 & 39.1 & 19.5 & 9.8 \\
\hline D-Mannose & - & - & - & - & + & + \\
\hline D-Galactose & + & + & + & + & + & + \\
\hline D-Glucose & + & + & + & + & + & + \\
\hline Fructose & + & + & + & + & + & + \\
\hline Sucrose & + & + & + & + & + & + \\
\hline $\begin{array}{l}\text { N-Acetyl-D-galactosamine } \\
\text { (GalNAc) }\end{array}$ & + & + & + & + & + & + \\
\hline $\begin{array}{l}\text { N-Acetyl-D-glucosamine } \\
\text { (GlcNAc) }\end{array}$ & + & + & + & + & + & + \\
\hline
\end{tabular}

range of environments including soil, fresh- and salt-waters, organic wastes playing a main role in ecosystems. Among the many Ascomycetes, some Penicillium species are grown for diverse industrial productions such as cheese, gluconic acid or several penicillin type antibiotics (particularly Penicillium chrysogenum for the latter). Due to the large scale production of these fungi and the availability of related industrial residues, we investigated the potential interesting proteins from Penicillium fungi such as lectins that could potentially categorised as new pesticidal proteins. In this study, a lectin from the Ascomycete fungus, $P$. chrysogenum was rapidly and effectively purified. Indeed, most of lectin purification corresponded to use of combined procedures including ammonium sulphate fractionation, gel-filtration, ion exchange and affinity chromatography methods. Here, the gel-filtration step was very efficient step which was already revealed to be useful to purify mannose-glucose specific lectin such as the Pisum sativum lectin

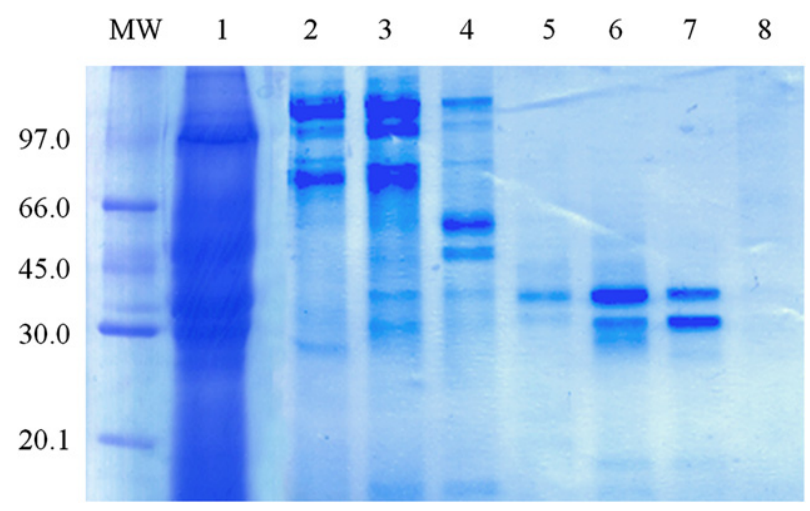

Fig 2 - SDS-PAGE of Penicillium chrysogenum lectin purification fractions. Lane 1: crude extract of $P$. chrysogenum, lane 2: fraction number 3 obtained during the purification, lane 3: fraction 4, lane 4: fraction 6; lane 5: fraction 8; lane 6: fraction 9; lane 7: fraction 10, and lane 8: fraction 11. Amersham molecular weight scale (MW) was added (Phosphorylase b, 97000 Da; Albumin, $66000 \mathrm{Da}$; Ovalbumin, $45000 \mathrm{Da}$; Carbonic anhydrase, $30000 \mathrm{Da}$; Trypsin inhibitor $20100 \mathrm{Da}$; $\alpha$-Lactalbumin, $14000 \mathrm{Da})$.

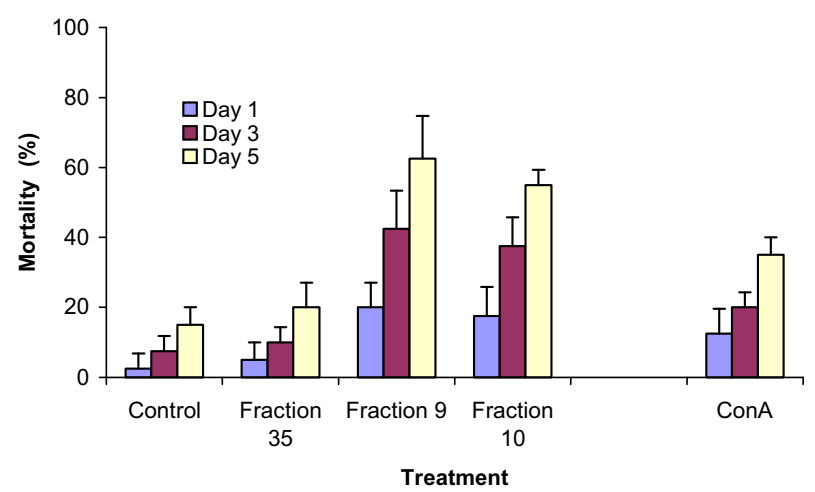

Fig 3 - Mortality of Myzus persicae when fed with fractions 9 and 10 from PECL purification procedure and ConA at $0.1 \%$ $\left(w^{-1} \mathbf{v}^{-1}\right)$ concentrations. Controls include a lectin-free artificial diet and an inert fraction 35 containing PBS.

from industrial pea protein extraction residues (CuertaroDiaz, unpubl.). The aim of the proposed purification procedure was to obtain a highly purified, active lectin fraction using a simple, rapid and low cost technique.

With a more than 12-fold purification factor related to the most concentrated fraction, the yield obtained for P. chrysogenum lectin (PeCL) was in the same range that other purified fungal lectins after combined chromatography procedures and the recovery yield of PeCL was relatively higher (2-25\%) than those previously reported for purified fungal lectins (Liu et al. 2004; Jung et al. 2007). Mushroom lectins previously purified were mainly proteins from Basidiomycetes such as Agaricus,
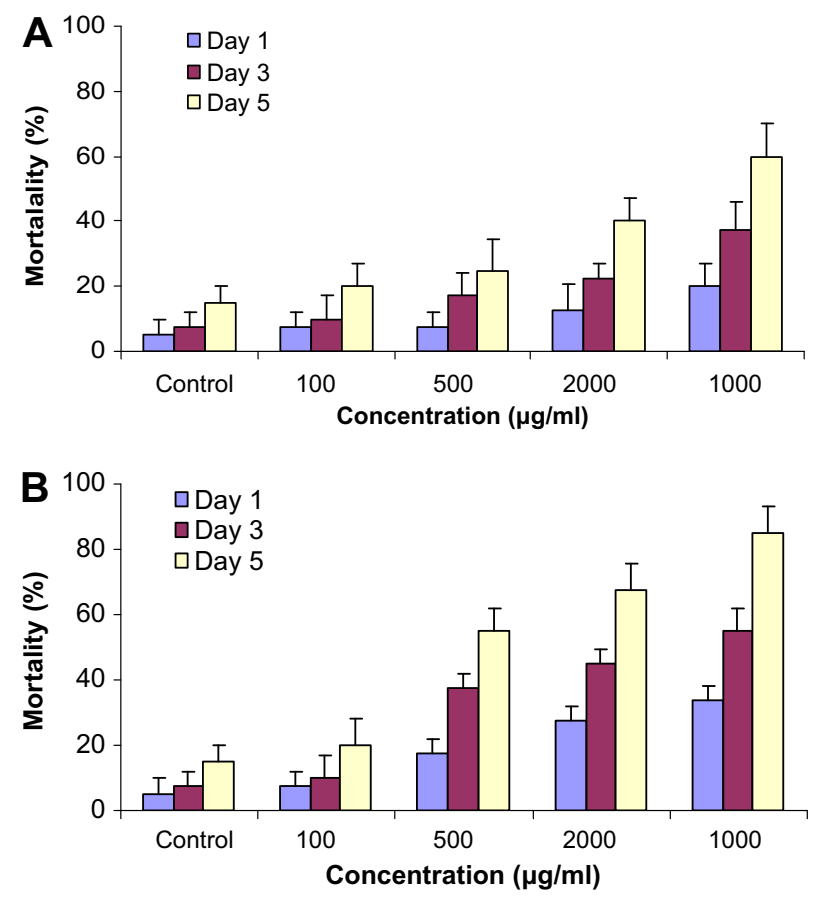

Fig 4 - Mortality of Myzus persicae when fed with increasing concentrations ( $w v^{-1}$ ) of (A) ConA or (B) PECL where the control represents a lectin-free diet. 
Pleurotus, and Xerocomus (Kawagishi et al. 1988; Trigueros et al. 2003; Wang \& Ng 2003; Li et al. 2008). In comparison relatively few lectins have been reported from Ascomycetes, namely from Aleuria aurantia, Melastiza chateri, Ciborinia camelliae, Sclerotinia sclerotiorum, Xylaria hypoxylon, and Cordyceps mimitaris (Jung et al. 2007). No direct homology was found with available sequences of nucleic acid from P. chrysogenum in NCBI. Mushroom lectins have a diverse range of molecular mass and subunit number, some are dimers or tetramers with subunit molecular mass from 12 to $41 \mathrm{kDa}$, other are monomers with the same range of molecular mass ( $\mathrm{Ng} \&$ Lam 2002; Otta et al. 2002). Here two bands were observed on SDS-PAGE with 31 and $40 \mathrm{kDa}$ weight. These bands were cut and the polypeptides were trypsin digested before being analysed by mass spectrometry. Both bands were found to correspond to lectin. PeCL seems to be derived from differential processing such as glycosylation of the lectin such as for ConA in plant.

Sugar-binding specificity of purified PeCL was tested according to several carbohydrate inhibition tests and revealed that our lectin was mannose specific. A sequence homology was identified with a mannose lectin from Zea mays according to the mass spectrometry analysis. Mannose-binding lectins are considered as biologically important proteins because mannose is widely distributed in microorganisms and animals including insects (Wong et al. 2008). Based on our previous works where fungal lectins were identified with potential insecticidal properties (Francis et al. 2003; Karimi et al. 2006; Karimi et al. 2007) the potential toxic effect of PeCL was investigated on aphids. PeCL lectin was shown to be highly toxic to Myzus persicae when compared to the lectin ConA which is known to have glucose- and mannose-binding properties. Similar entomotoxic property was observed by Trigueros et al. (2003) using another mushroom with Xerocomus chrysentron lectin (XCL) when Drosophila melanogaster fly and Acyrthosiphon pisum aphid were fed with XCL in artificial diets. After a comparison of XCL and ConA towards two aphid species, XCL was more aphicidal than ConA (Karimi et al. 2006; Karimi et al. 2007). According to the toxicological results from this study, both XCL and PeCL were found to be similarly entomotoxic and could be considered as potential insecticidal proteins to control aphids. Indeed, significant aphid mortality was observed from $0.05 \%$ PeCL concentration in artificial diet.

Among the insect pest orders, some Hemiptera cause serious damage to many crop plants by directly extracting the nutrients from the plants but also by acting as virus vectors (Barton et al. 1987; Peferoen et al. 1990). According to the direct toxic effect of lectins on insect biological parameters (Gatehouse et al. 1984; Down et al. 2003; Sauvion et al. 2004) but also to the potential competitive effect of lectins towards viral particles in virus transmission by aphids, fungal lectins such as PeCL represent a very promising protein to control aphid pest damages in crops.

\section{Acknowledgement}

We would like to thank the government of Iran for funding Karimi J. during his stay in Belgium and Gembloux Agricultural University for the funding of the experimental works.
R E F E R E N C E S

Barton K, Whiteley H, Yang NS, 1987. Bacillus thuringiensis deltaendotoxin in transgenic Nicotiana tabacum provides resistance to lepidopteran insects. Plant Physiology 85: 1103-1109.

Bradford MM, 1976. A rapid and sensitive method for the quantitation of microgram quantities of protein utilizing the principle of protein-dye binding. Analytical Biochemistry 72: 248-254.

Down RE, Ford L, Woodhouse SD, Davison GM, Majerus MEN, Gatehouse JA, Gatehouse AMR, 2003. Tritrophic interactions between transgenic potato expressing snowdrop lectin (GNA), an aphid pest (peach-potato aphid; Myzus persicae) and a beneficial predator (2-spot ladybird; Adalia bipunctata L.). Transgenic Research 12: 229-241.

Febvay G, Bonnin J, Rahbe Y, Bournoville R, Delrot S, Bonnemain JL, 1988. Resistance of different lucerne cultivars to the pea aphid Acyrthosiphon pisum: influence of phloem composition on aphid fecundity. Entomologia Experimentalis et Applicata 48: 127-134.

Fitches E, Woodhouse SD, Edwards JP, Gatehouse JA, 2001. in vitro and in vivo binding of snowdrop (Galanthus nivalis agglutinin; GNA) and jackbean (Canavalia ensiformis; Con A) lectins within tomato moth (Lacanobia oleracea) larvae; mechanisms of insecticidal action. Journal of Insect Physiology 47: 777-787.

Francis F, Marty-Detraves C, Poincloux R, Baricault L, Fournier D, Paquereau L, 2003. Fungal lectin, XCL, is internalized via clathrin-dependent endocytosis and facilitates uptake of other molecules. European Journal of Cell Biology 82: 515-522.

Gatehouse AMR, Dewey FM, Dove J, Fenton KA, Pusztai A, 1984. Effect of seed lectins from Phaseolus vulgaris on the development of larvae of Callosobruchus maculatus; mechanism of toxicity. Journal of the Science of Food and Agriculture 35: 373-380.

Guillot J, Konska G, 1997. Lectins in higher fungi. Biochemical Systematics and Ecology 25: 203-230.

Habibi J, Backus EA, Huesing JE, 2000. Effects of phytohemagglutinin (PHA) on the structure of midgut epithelial cells and localization of its binding sites in western tarnished plant bug, Lygus hesperus Knight. Journal of Insect Physiology 46: 611-619.

Habibi J, Backus EA, Czapla TH, 1998. Subcellular effects and localization of binding sites of phytohemagglutinin in the potato leafhopper, Empoasca fabae (Insecta: Homoptera: Cicadellidae). Cell and Tissue Research 294: 561-571.

Harper SM, Crenshaw RW, Mullins MA, Privalle LS, 1995. Lectin binding to insect brush border membranes. Journal of Economic Entomology 88: 1197-1202.

Hamshou M, Smagghe G, Shahidi-Noghabi S, De Geyter E, Lannoo N, Van Damme EJM, 2010. Insecticidal properties of Sclerotinia sclerotiorum agglutinin and its interaction with insect tissues and cells. Insect Biochemistry and Molecular Biology 40: 883-890.

Jung EC, Kim KD, Bay CH, Kim JC, Kim DK, Kim HHA, 2007. Mushroom lectin from ascomycete Cordyceps militaris. Biochimica et Biophysica Acta 1770: 833-838.

Karimi J, Paquereau L, Fournier D, Haubruge E, Francis F, 2006. Use of artificial diet system to assess the potential bio-insecticide effect of a fungal lectin from Xerocomus chrysenteron (XCL) on Myzus persicae. Communications in Agricultural and Applied Biological Sciences, Ghent University 71: 497-505.

Karimi J, Paquereau L, Fournier D, Haubruge E, Francis F, 2007. Effect of a fungal lectin from Xerocomus chrysenteron (XCL) on the biological parameters of aphids. Communications in Agricultural and Applied Biological Sciences, Ghent University 72: 629-638.

Kawagishi H, Nomura A, Yumen T, Mizuno T, 1988. Isolation and properties of a lectin from the fruiting bodies of Agaricus blazei. Carbohydrate Research 183: 150-154. 
Kilpatrick DC, 2002. Animal lectins: a historical introduction and overview. Biochimica et Biophysica Acta 1572: 187-197.

Laemmli UK, 1970. Cleavage of structural proteins during the assembly of the head of bacteriophage T4. Nature 227: 680-685.

Li YR, Liu QH, Wang HX, Ng TB, 2008. A novel lectin with potent antitumor, mitogenic and HIV-I reverse transcriptase inhibitory activities from the edible mushroom Pleurotus citrinopileatus. Biochimica et Biophysica Acta 1780: 51-57.

Liu Q, Wang H, Ng TB, 2004. Isolation and characterization of a novel lectin from the wild mushroom Xerocomus spadiceus. Peptides 25: 7-10.

Macedo MLR, Freire MGM, Silva MBR, 2007. Insecticidal action of Bauhinia monandra leaf lectin (BmoLL) against Anagasta kuehniella (Lepidoptera: Pyralidae), Zabrotes subfasciatus and Callosobruchus maculatus (Coleoptera: Bruchidae). Comparative Biochemistry and Physiology Part A: Molecular \& Integrative Physiology 146: 486-498.

$\mathrm{Ng}$ TB, Lam YW, 2002. Isolation of a novel agglutinin with complex carbohydrate binding specificity from fresh fruiting bodies of the edible mushroom Lyophyllum shimeiji. Biochemical and Biophysical Research Communications 290: 563-568.

$\mathrm{Ng} \mathrm{TB}, 2004$. Peptides and proteins from fungi. Peptides 25: 1055-1073.

Oda Y, Senaha T, Matsuno Y, Nakajima K, Naka R, Kinoshita M, Honda E, Furuta I, Kakehi K, 2003. A new fungal lectin recognizing alpha (1-6)-linked fructose in the $\mathrm{N}$-glycan. Journal of Biological Chemistry 278: 32439-32447.

Otta YKA, Nishiyama K, Ando A, Ogawa S, Nagata Y, 2002. Purification and properties of a lectin from ascomycete mushroom, Ciborinia camelliae. Phytochemistry 60: 103-107.

Peferoen M, Jansens S, Reynaerts A, Leemans J, 1990. Potato plants with engineered resistance against insect attack. In: Vayda ME, Park WC (eds), Molecular and Cellular Biology of Potato. CAB International, Wallingford, pp. 193-204.

Peumans WJ, Van Damme EJM, 1995. Lectins as plant defense proteins. Plant Physiology 109: 347-352.

Powell KS, Spence J, Bharathi M, Gatehouse JA, Gatehouse AMR, 1998. Immunohistochemical and developmental studies to elucidate the mechanism of action of the snowdrop lectin on the rice brown planthopper, Nilaparvata lugens (Stal). Journal of Insect Physiology 44: 529-539.
Powell KS, 2001. Antimetabolic effects of plants lectins towards nymphal stages of the planthoppers Tarophagous proserpina and Nilaparvata lugens. Entomologia Experimentalis et Applicata 99: 71-77.

Qi G, Lan N, Ma X, Yu Z, Zhao X, 2011. Controlling Myzus persicae with recombinant endophytic fungi Chaetomium globosum expressing Pinellia ternata agglutinin using recombinant endophytic fungi to control aphids. Journal of Applied Microbiology 110: 1314-1322.

Rudiger H, Gabius HJ, 2001. Plant lectins: occurrence, biochemistry, functions and applications. Glycoconjugate Journal 18: 589-613.

Sauvion N, Rahbe Y, Peumans WJ, Van Damme EJM, Gatehouse JA, Gatehouse AMR, 1996. Effects of GNA and other mannose binding lectins on development and fecundity of the potato-peach aphid Myzus persicae. Entomologia Experimentalis et Applicata 79: 285-293.

Sauvion N, Nardon C, Febvay G, Gatehouse AMR, Rahbe Y, 2004. Binding of the insecticidal lectin Concanavalin A in pea aphid, Acyrthosiphon pisum (Harris) and induced effects on the structure of midgut epithelial cells. Journal of Insect Physiology 50: 1137-1150.

Trigueros V, Lougarre A, Ali-Ahmed D, Rahbe Y, Guillot J, Chavant L, Fournier D, Paquereau L, 2003. Xerocomus chrysenteron lectin: identification of a new pesticidal protein. Biochimica et Biophysica Acta 1621: 292-298.

Van Damme EJM, Peumans WJ, Pusztai A, Bardocz S, 1998. Handbook of Plant Lectins: properties and biomedical applications. John Wiley and Sons, Oxford, p. 452.

Wang HX, Ng TB, Ooi VEC, 1998. Lectins from mushroom. Mycological Research 102: 897-906.

Wang $\mathrm{H}, \mathrm{Ng} \mathrm{TB}, 2003$. Isolation of a novel $\mathrm{N}$-acetylglucosaminespecific lectin from fresh sclerotia of the edible mushroom Pleurotus tuber-regium. Protein Expression and Purification 29: 156-160.

Wang H, Wong CCT, Ng TB, 2006. Purification and characterization of a galactose-specific lectin with mitogenic activity from pinto beans. Biochimica et Biophysica Acta 1760: 808-813.

Wong H, Chan HYE, Ng TB, 2008. A mannose/glucose-specific lectin from Chinese evergreen chinkapin (Castanopsis chinensis). Biochimica et Biophysica Acta 1780: 1017-1022. 